\title{
Phytochemical Analysis and Vitamin Composition of Irvigna Gabonesis and Citrullus Colocynthis
}

\author{
*Igwenyi, I. O. \\ Department of Biochemistry, Ebonyi State University, Abakaliki, Ebonyi, Nigeria
}

\begin{abstract}
Chemical analysis on Citrullus colocynthis and Irvigna gabonesis seeds was carried out to predict their possible medicinal value and therapeutic applications using standard methods. Analysis of vitamin contents revealed that the seeds were predominantly composed of water soluble vitamins. Vitamin $B_{1}, B_{2}, B_{6}$ and $B_{12}$ contributed a total of $610.15 \mathrm{mg} / 100 \mathrm{~g}$ and $898.66 \mathrm{mg} / 100 \mathrm{~g}$ in Citrullus colocynthis and Irvigna gabonesis respectively. Vitamin $C$ was high in both seeds with values for Citrullus colocynthis 67.80 and Irvigna gabonesis $112.13 \mathrm{mg} / 100 \mathrm{~g}$. Investigation into the level of plants secondary metabolites showed that the seeds were composed of bioactive components. The phytochemical composition revealed high concentration of tannins and alkaloids. Some antinutrients such as phytate, cyanogenic glycosides, hemagluttinin, saponins and oxalates were present at very low concentrations. Flavonoids, steroids, terpenoids and phenols were also present at high concentrations while beta carotene occurred at very low concentration of $0.31 \pm 0.01$ and $0.92 \pm 0.01 \mathrm{mg} / 100 \mathrm{~g}$ for Irvigna gabonesis and Citrullus colocynthis respectively. The high concentration of vitamin $C$, flavonoids and phenols were indicative of high antioxidant activity.
\end{abstract}

\section{Introduction}

Investigation into the components of medicinal plants is a very popular subject of research in chemical and related biological sciences in most developing countries of the world. Some of these plant materials have been known to provide alternative natural products to synthetic and imported drugs. This is the basis for the application of nutrition in therapy and treatment of ailments and diseases as well as provision of raw materials for local pharmaceutical industries (Martin, 2000).

In the Igbo speaking South-Eastern Nigeria, soup is in the center of the people's food and culture. Soups are prepared to accompany almost all carbohydrate based food and form part of preparations married women carry when visiting their parents and elders. Condiments are plant seeds that are added to enrich and enhance flavour of soup while thickeners are substances added to "thicken" and add bulk or body to soup which helps to stimulate appetite and aid swallowing (Fernandez-Armesto, 2002). These seeds form an important part of the West and Central African diet, providing carbohydrate and protein (Onyeike et al., 1994) and they include seeds of Citrullus colocynthis (melon) and Irvigna gabonnesis (bush mango).

Citrullus colocynthis is a seed crop and the commonest soup condiment enjoyed in the south-east region of Nigeria while Irvigna gabonesis has the ability to form gels at lower concentration than many oil seed flours and this is why they are applied in food industry that require a thickening agent (Ejiofor, 1994).

\section{Materials And Methods:}

The samples used were fresh local indigenous seeds picked from farms in Okposi autonomous community in Ohaozara Local Government Area, Ebonyi State, Nigeria. They were dried in an oven at $60^{\circ} \mathrm{C}$ for 48 hours and later milled with blender to reduce the particle size and increase the surface area and used for the analyses.

VITAMIN ANALYSIS: Official methods involving various spectrophotometric and titrimetric methods were employed in vitamin assay of the samples. The methods of Blake (2005) were employed in the vitamin analysis.

PHYTOCHEMISTRY: Generally, the spectrophotometric methods were used in the analysis of the phytochemical compositions. Methods of Harbone, 1973 and Okwu and Ndu (2006) were used for the phytochemical analysis of the antinutrients composition.

RESULTS 


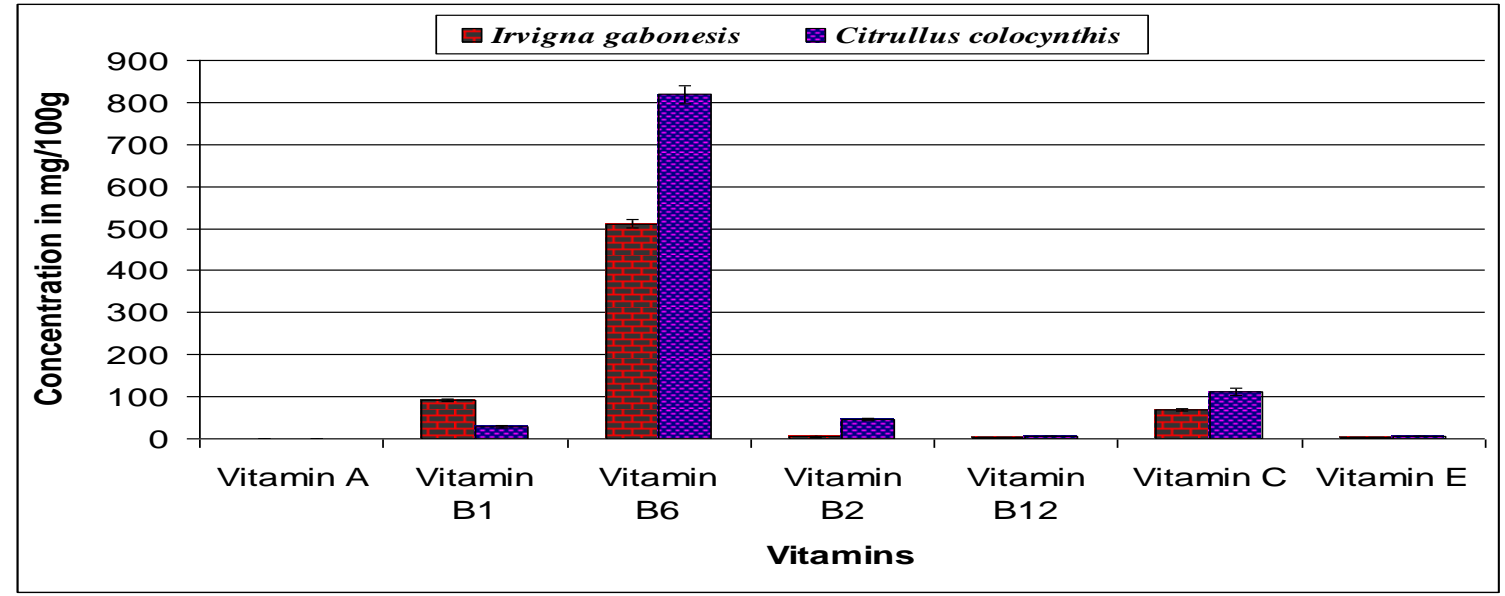

Figure 1: VITAMIN COMPOSITION OF IRVIGNA GABONESIS AND CITRULLUS COLOCYNTHIS IN $\mathrm{mg} / 100 \mathrm{~g}$ OF SEED SAMPLE.

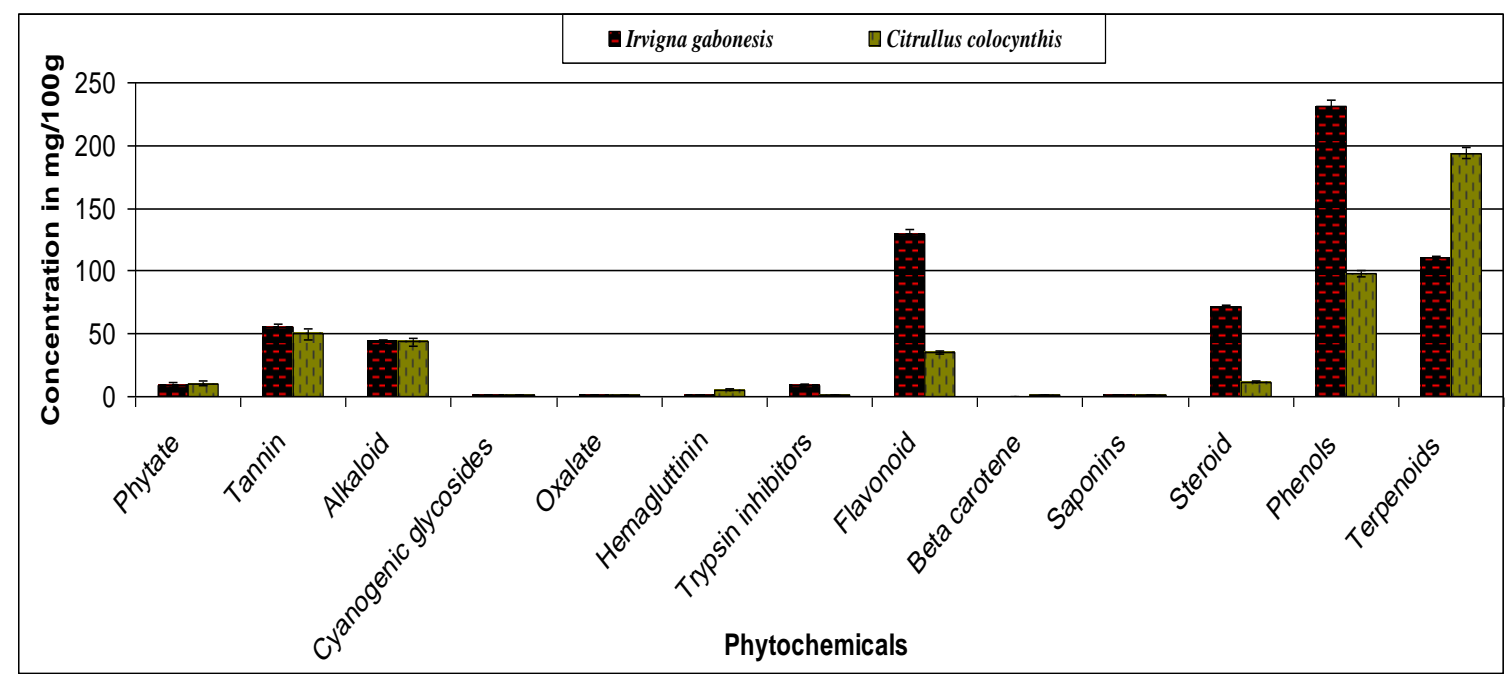

Figure 2: ANTINUTRIENT FACTORS/PHYTOCHEMICAL COMPOSITION OF IRVIGNA GABONESIS AND CITRULLUS COLOCYNTHIS IN mg/100g.

Investigation into the vitamin content as shown in figure 1 revealed that the seeds were predominantly composed of water soluble vitamins. They were rich in vitamin $\mathrm{B}_{6}, \mathrm{~B}_{1}$ and vitamin $\mathrm{C}$. Vitamins $\mathrm{B}_{1}, \mathrm{~B}_{2}, \mathrm{~B}_{6}$ and $\mathrm{B}_{12}$ contributed a total of $610.15 \mathrm{mg} / 100 \mathrm{~g}$ and $898.66 \mathrm{mg} / 100 \mathrm{~g}$ in Citrullus colocynthus and Irvigna gabonesis respectively. Vitamin C was also high in both seeds with values for Colocynthus citrullus 67.80 and Irvigna gabonesis $112.13 \mathrm{mg} / 100 \mathrm{~g}$. This result is comparable to values for seeds used as soup thickeners in south Eastern parts of Nigeria (Igwenyi and Akubugwo, 2010).

Vitamins are organic components in food that are needed in very small amounts for growth and for maintaining good health (Freeland and Briggs, 1980). They have diverse biochemical functions. Water-soluble vitamins dissolve easily in water, and in general, are readily excreted from the body, to the degree that urinary output is a strong prediction of vitamin consumption (Fukuwatari, 2008). Because they are not readily stored, consistent daily intake is important (Said and Mohammed, 2006). Fat soluble vitamins such as vitamin A and E were low in the two seeds. Fat-soluble vitamins are absorbed through the intestinal tract with the help of lipids (fats). Because they are more likely to accumulate in the body, they are more likely to lead to hypervitaminosis than are water-soluble vitamins (Maqbool and Stallings, 2008). This result showed that their consumption will not lead to hypervitaminosis as the high solubility of water soluble vitamins enhances their excretion through the urine.

Phytochemical analysis in figure 2 showed that they were made up of some bioactive compounds and antinutrients. Anti-nutrients are natural or synthetic compounds that interfere with the absorption of nutrients. Nutrition studies also focuses on those anti-nutrients commonly found in food sources and beverages (Oomen $e t$ al., 1978). The investigation in table 2 showed that they were predominantly composed of tannins and alkaloids. The concentration of antinutrients in Citrullus colocynthis was tannins 49.67, alkaloids 43.63, phytates 10.6, 
cyanogenic glycosides 1.58 , oxalates 1.30 , Hemagluttinin 5.63 and trypsin inhibitor $0.75 \mathrm{mg} / 100 \mathrm{~g}$. The concentration of these phytochemicals in Irvigna gabonesis were tannins 54.75, alkaloids 43.63, phytate 9.30, trypsin inhibitor 9.37 , cyanogenic glycosides 1.43 , oxalates 1.08 and hemagluttinin $0.95 \mathrm{mg} / 100 \mathrm{~g}$.

Trypsin inhibitors are chemicals that reduce the availability of trypsin, an enzyme essential to nutrition of many animals, including humans (Pearson, 2005). Many metal ions form insoluble precipitate with oxalate, a prominent example being calcium oxalate of most kidney stones (Engin et al., 2007). Thus in the body, oxalic acid also combines with metal ions such as $\mathrm{Ca}^{2+}, \mathrm{Fe}^{2+}$, and $\mathrm{Mg}^{2+}$ to deposit as crystals of the corresponding oxalates, which irritate the gut and kidneys. Because it binds vital nutrients such as calcium, long-term consumption of foods high in oxalic acid can be problematic. Phytic acid is an anti-nutrient that interferes with absorption of minerals from the diet. Phytates form insoluble complexes and affect the bioavailability of minerals such as calcium, zinc, iron and magnesium. Hemagglutinin refers to a substance that causes the red blood cells to agglutinate. This process is called hemagglutination (Fouchier et al., 2005; Nelson and Cox, 2005). Tannins are astringent, bitter plant polyphenols that either bind and precipitate or shrink proteins. The astringency from the tannins is what causes the dry and puckery feeling in the mouth following the consumption of red wine or an unripened fruit. Tannins have traditionally been considered antinutritional but it is now known that they have beneficial properties that have both therapeutic and pharmacological effects, which depend upon their chemical structure and dosage (Mueller-Harvey and McAllan, 1992. Saponins destroy the red blood cells by hemolysis and are toxic especially to cold blooded animals. Many have been used as fish poisons as they are toxic to aquatic life (Baranov, 1966). Saponins taken orally facilitate the absorption of certain substances like food and medicine and also acts as laxatives, diuretics and expectorants (Baumargata, 1963). Their medicinal value is due to their expectorant effect. Flavonoids were recognized for their popular use in the treating wounds and local microbial infection. Flavonoids are most commonly known for their antioxidant activity. More recently, their anti-viral, anti-inflammatory activities have been reported. Flavonoids have been referred to as "nature's biological response modifiers" because of strong experimental evidence of their inherent ability to modify the body's reaction to allergens, viruses, and carcinogens. They show anti-allergic, anti-inflammatory (Yamamoto and Gaynor, 2006), anti-microbial and anti-cancer activity (Cushnie and Lamb, 2005).

Many traditional methods of food preparation such as roasting, fermentation, cooking, and malting increase the nutritive quality of plant foods through reducing certain anti-nutrients such as phytic acid, polyphenols, and oxalic acid. Such processing methods are widely used in societies where cereals and legumes form a major part of the diet and processing reduces the levels of both toxins and anti-nutrients in the tuber (Champer et al., 2005).

\section{Conclusion:}

Citrullus colocynthus and Irvigna gabonesis are used for nutritional purpose as it contains useful nutrients such as carbohydrate, minerals and essential amino acids (Igwenyi et al., 2011). The predominance of water soluble vitamins indicates that there may not be an unusual accumulation of vitamins that may lead to hypervitaminosis. The phytochemical analysis revealed that the seeds contain bioactive secondary metabolites that may find useful applications in medicine and pharmacology.

\section{References}

[1] Baumargata, T. (1963). Biochemistry of Saponins and phonelic compounds. Journal of Biochemistry, 15: 1332 - 1335.

[2] Blake, C. (2005). Vitamins and other Nutrients. In: Horwitz, W. and Latimer, G. (Editorials), Official Methods of Analysis of AOAC International. $18^{\text {th }}$ edition. USA: 1-57.

[3] Champer, C. P., Harvey, R. A. and Fernior, D. R. (2005). Biochemistry: Lippincotts Illustrated Reviews, Jaypee Brothers Medical Publishers Ltd.

[4] Cushnie, T. P. and Lamb, A. J. (2005). Antimicrobial activity of flavonoids. International Journal of Antimicrobial Agents. 26(5): 343-356.

[5] Ejiofor, M. A. N. (1994). Nutritional value of Ogbono (Irvigna gabonesis var. excelsa). Proceedings of the ICRAF-IITA Conference on Irvigna gabonesis, Ibadan, Nigeria. May 20, 1994,

[6] Engin, K. N., Engin, G. K., Kucuksasin, H. O. and Gurrner, B. (2007). Clinical Evaluation of the Neuroprotective Effect of alpha Tocopherol against Glaucomatous Damage. European Journal of Opthamology, 17: 528-533.

[7] Fernandez-Armesto, F. (2002). Near a Thousand Tables: A History of Food. New York: Free Press.

[8] Fouchier, R. A. M., Munster, v., Wallensten, A., Bestebroer, T. M. and Herfst, S. (2005). Characterization of a Novel Influenza A virus Hemagglutinin Subtype (H16) Obtained from Black-headed Gulls. Journal of Virology. 79(5): 2814 - 2822.

[9] Freeland, R. A. and Briggs, S. (1980). A Biochemical Approach to Nutrition. Chapman and Hall, New York.

[10] Fukuwatari, T. and Shibatata, K. (2008). "Urinary water-soluble vitamins and their metabolite contents as nutritional markers for evaluating vitamin intakes in young Japanese women". Nutr. Sci. Vitaminol. 54(3): 223-9.

[11] Harbone, J. B. (1973). Textbook of Phytochemical Methods: A guide to modern techniques of plant analysis. $2^{\text {nd }}$ edition. Chapman and Hall LTD, London.

[12] Hoffman, G. (1986). Ouality Control in Food Industry, Food Science and Technology Series of Monographs, $2^{\text {nd }}$ edition, Academic press, London, 2, 407-504.

[13] Igwenyi, I. O. and Akubugwo, E. I. (2010). Analysis of Four Seeds Used as Soup Thickeners in the South Eastern Parts of Nigeria. Conference Proceedings: International Conference on Chemistry and Chemical Engineering, (ICCCE, 2010), August 1-3, 2010, Kyoto International Conference Center, Kyoto, Japan. 2010. $426-430$. 
[14] Igwenyi, I. O., Eze. C. A., Azoro, B. N., Offor, C. E. and Nwuke, C. P. (2011). Proximate, Mineral and Amino Acid Compositions of Irvigna gabonesis and Citrullus colocynthis Used as Soup Thickener in South Easter Nigeria. International Journal of Biotechnology and Biochemistry. 7(4): 493-499.

[15] Martin, F. C. (2000). Modern Approaches for Selecting Biologically Activev Plants. Journal of Pharmacological Sciences, 63: 458460.

[16] Maqbool, A. and Stallings, V. A. (2008). "Update on fat-soluble vitamins in cystic fibrosis". Curr Opin Pulm Med 14 (6): $574-81$.

[17] Mueller-Harvey, I. and McAllan, A. B. (1992). Tannins: Their biochemistry and nutritional properties. Advances in Plant Cell Biochemistry and Biotechnology. 1: 151-217.

[18] Nelson, D. L. and Cox, M. M. (2005). Lehniger principle of Biochemistry. $5^{\text {th }}$ edition. W.H. Freeman and Company. New York. $172-186,827$.

[19] Okwu, D. E. and Ndu, C. U. (2006). Evaluation of the phytonutrients, mineral and vitamin contents of some varieties of yam (Dioscorea sp). Int. J. Mol. Med. and Advance Sci. 12(2): $199-203$.

[20] Onyeike, E. N., Olungwe, T. and Uwakwe, A. A. (1995). Effect of Heat Treatment and Defatting on the Proximate Composition of Some Nigerian Local Soup Thickeners. Food Chemistry, 1995. 53:173-175.

[21] Oomen, H. C. and Grubben, A. (1978). Tropical leaf vegetables in human nutrition. Journal of Agriculture, 20: 69 - 75

[22] Pearson, D. A. (2005). Chemical Analysis of Food. $7^{\text {th }}$ edition, Churchill Livingstone, Edinburgh.

[23] Said, H. M. and Mohammed, Z. M. (2006). Intestinal absorption of water-soluble vitamins: An update". Curr. Opin. Gastroenterol., 22(2): 140-146.

[24] Yamamoto, Y. and Gaynor, R. B. (2001). Therapeutic potential of inhibition of the NF-kappaB pathway in the treatment of inflammation and cancer. Journal of Clinical Investigation. 2006. 